\title{
湿式法を用いた空気清浄装置のたばこ煙および臭気除去性能評価(第1報)
}

野口美由貴1)，水越厚史 ${ }^{2)}$ ，前田康博3)，佐伯寅彦3)，湯懐鵬 ${ }^{3)} ，$ 柳沢幸雄 ${ }^{4}$

1)成蹊大学， ${ }^{2}$ 東京都立産業技術研究センター， ${ }^{3}$ 新菱冷熱工業株式会社， ${ }^{4}$ 東京大学

\section{Performance evaluation of air cleaning equipment in terms of ETS (Environmental Tobacco Smoke) and odor removal (Part 1)}

\author{
Miyuki NOGUCHI ${ }^{1}$, Atsushi MIZUKOSHI ${ }^{2)}$, Yasuhiro MAEDA ${ }^{3)}$, Torahiko SAEKI ${ }^{3)}$, \\ Huaipeng $\mathrm{TANG}^{3)}$ and Yukio YANAGISAWA ${ }^{4}$
}

\footnotetext{
${ }^{1)}$ Faculty of Science and Technology, Seikei University, 3-3-1, Kichijoji-kitamachi, Musashino-shi, Tokyo, 180-8633, Japan

${ }^{2)}$ Tokyo Metropolitan Industrial Technology Research Institute, 2-4-10, Aomi, Kouto-ku, Tokyo, 135-0064, Japan

${ }^{3}$ SHINRYO CORPORATION, 41, Wadai, Tsukuba, Ibaraki, 300-4247, Japan

${ }^{4)}$ Graduate School of Frontier Sciences, The University of Tokyo, 5-1-5, Kashiwanoha, Kashiwa, Chiba, 277-8563, Japan
}

\section{要 旨}

既存の空気清浄手法に湿式法による臭気除去ユニットを加えた空気清浄装置(以下開発装置)について，臭 気成分であるアセトアルデヒドを含むたばこ煙成分の除去効果をプロトン移動反応質量分析計(PTR-MS)に より経時的に評価した。開発装置は, 高性能除じんフィルター, 活性炭フィルターから成る粉じん・VOC 除去ユニット（Particulate and VOC Removal Unit：PVRU)の後段に新たに開発されたアミノ酸を含む薬液(化 学吸収液)を用いた湿式の臭気除去ュニット(Odor Removal Unit：ORU)を配している。

実験ではアセトアルデヒドガスあるいはたばこ煙を開発装置に連続的に導入し，装置吸入口，PVRU後， ORU後(装置吹出口)の3点に打いて試料空気中のアセトアルデヒド，たばこ煙成分および臭気濃度を測定し， 各ユニットの除去効率を比較した。その結果，PVRU後では浮遊粉じん，ニコチンなど多くの揮発性有機化 合物 (VOC)の除去効果が認められたが，カルボニル化合物などの含酸素有機化合物之臭気の除去効果は不 十分であり，アセトアルデヒドの除去率は時間経過ととあに低下した。これに対してORU後ではアセトア ルデヒドの $95 \%$ が除去され，臭気は $99 \%$ 低減した。この効果はのべ400本のたばこ燃焼時まで持続し，薬液 のアセトアルデヒド吸収容量は70 $\mathrm{mg} \mathrm{L} \mathrm{L}^{-1}$ 以上であった。

\begin{abstract}
Removal efficiencies of environmental tobacco smoke (ETS) and its odor with newly developed ETS removal equipment were evaluated. The developed equipment consists of two units: Particulate and VOC Removal Unit (PVRU) and Odor Removal Unit (ORU) connected in series. The $1^{\text {st }}$ unit is PVRU for removing suspended particulate matter (SPM) and volatile organic compounds (VOC) composed of two air filters (HEPA: High Efficiency Particulate Air filter and activate charcoal filter). The $2^{\text {nd }}$ unit is ORU for removing acetaldehyde and ETS odor composed of a wet element using chemical absorbent containing amino acids mixture. First, removal experiment of acetaldehyde in air was carried out. In the experiment, we measured acetaldehyde concentration at inlet of PVRU, and outlet of ORU. Removal efficiency of acetaldehyde by the developed equipment was higher than $90 \%$. Next, removal experiment of ETS and its odor was carried out during tobacco smoke generating. We found that SPM and most of VOC except oxygenated compounds were almost completely removed by PVRU. The removal efficiencies of acetaldehyde and odor by PVRU were $80 \%, 90 \%$ respectively, and the removal efficiency of acetaldehyde was decreased with time. But the removal efficiencies of these components after ORU were $95 \%, 99 \%$ respectively. Acetaldehyde is considered to be chemically absorbed by amino acids in the chemical absorbent, and its absorption capacity of acetaldehyde was at least $70 \mathrm{mg} \mathrm{L}^{-1}$. The removal efficiency was confirmed to be maintained after treatment of tobacco smoke of 400 cigarettes.
\end{abstract}

Key words: 環境たばこ煙(Environmental Tobacco Smoke), 臭気(Odor), アセトアルデヒド (Acetaldehyde), 粉じん・VOC除去ユニット (Particulate and VOC Removal Unit), 臭気除去ユニット(Odor Removal Unit)，プロトン移動反応質量分析計(Proton Transfer Reaction Mass Spectrometry) 


\section{1. 緒言}

空気清浄機の開発では, シックハウス症候群ある いはアレルギーの原因物質である揮発性有機化合物 （VOC）やホルムアルデヒド, 浮遊粉じんの除去を 目的として抢り，その初期除去効率をむって性能評 価が行われてきた ${ }^{1,2)}$ 。しかしカルボニル化合物など の含酸素有機化合物は, 活性炭による長期除去が難 しいことが知られている3”。特にたばこ煙のように 浮遊粉じんと多種類のVOCやカルボニル化合物を 含む場合, 浮遊粉じんや一部のVOCについては除 去できるもののカルボニル化合物などについては十 分な除去が達成できないとの報告がなされている

一般に空気清浄機の性能評価では，チャンバー内 に装置を設置した後，VOCなどの処理対象物質を 導入し，これらの濃度減衰を指標(67) とする場合が多 いが，この場合装置に導入される処理対象物質の濃 度は経時的に变化する。これに対し, 本研究で採用 した装置内を污染空気が一回通過した際の除去効率 (ワンパス除去率)による評価 ${ }^{8}$ では, 空気清浄機に 導入される処理対象物質濃度を一定に保ちながら清 浄機の空気清浄性能評価を行う。ワンパス除去率に よる評価では, 対象とする各々の物質の除去効果を 容易に評価することができ，多段の空気清浄ユニッ 卜を組み入れた装置では，ユニット毎の除去効果を 知ることができる点で有利であると考えられる。

一方, 喫煙による健康影響の問題は, 喫煙者だけ に留まらず非喫煙者に対しても受動喫煙という形で,
同様の健康影響を与えると考えられており9), 喫煙 者と非喫煙者が共に快適な生活空間を共有しょうと するときには，その臭気も課題となる。したがって， たばこ煙除去を目的とする空気清浄機には，たばこ 煙に由来する浮遊粉じん，VOCなどのたばこ煙特 有の化学物質の除去とたばこ煙の臭気の除去性能が

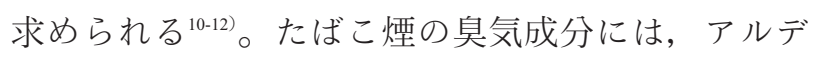
ヒド類や脂肪酸などの含酸素物質やアンモニア，ピ リジンなどの含窒素物質, 硫化水素などの含硫黄物 質などが挙げられる ${ }^{13)}$ 。たばこ煙の除去効果は浮遊 粉じんやニコチンなどに加えカルボニル化合物やア ンモニアなどの評価も重要である。そこで本研究で は新たに開発されたたばこ煙除去装置 (以下開発装 置)について, 浮遊粉じん, VOC, アセトアルデヒ ド, アンモニア, 臭気の除去性能について評価した。

\section{2. たばこ煙に対するアセトアルデヒドの臭気寄与}

厚生労働省の報告では, 副流煙中の一酸化炭素や 窒素酸化物, タール分の他, 20 種類の化学物質の含 有量について報告されている ${ }^{14)}$ 。Table 1に示した 化学物質濃度の合計からそれぞれの化学種の濃度割 合を計算すると, カルボニル化合物の占める割合は およそ $20 \%$ となる。さらにカルボニル化合物の中で は銘柄に関わらずホルムアルデヒド，アセトアルデ ヒド，アセトンの濃度が高く，その中でもアセトア ルデヒドは全カルボニル化合物の $40 \%$ 以上を占める。 また, 副流煙中の化学成分濃度をその嗅覚閾値 ${ }^{15)}$ で

Table 1 Content, threshold and odor unit of secondhand smoke components

\begin{tabular}{lccc}
\hline \hline \multicolumn{1}{c}{ Component } & $\begin{array}{c}\text { Content }^{14)} \\
\left(\mu \text { g cigarette }^{-1}\right)\end{array}$ & $\begin{array}{c}\text { Threshold }^{15)} \\
\left(\mu \mathrm{g} \mathrm{m}^{-3}\right)\end{array}$ & $\begin{array}{c}\text { Odor Unit* } \\
(-)\end{array}$ \\
\hline Nicotine & 4480 & 79.5 & 56 \\
Ammonia & 6923 & 1140 & 6.1 \\
Formaldehyde & 423 & 670 & 0.6 \\
Acetaldehyde & 1789 & 2.95 & 607 \\
Acetone & 1023 & 109000 & 0.0 \\
Acrolein & 314 & 9.00 & 35 \\
Propionaldehyde & 185 & 2.59 & 71 \\
Crotonaldehyde & 62.7 & 71.9 & 1 \\
Methylethylketone & 210 & 1410 & 0.0 \\
Butylaldehyde & 121 & 2.15 & 56 \\
1,3-Butadiene & 376 & 555 & 0.7 \\
Isoprene & 2516 & 146 & 17.3 \\
Acrylonitrile & 104 & 20800 & 0.0 \\
Benzene & 303 & 9400 & 0.0 \\
Toluene & 618 & 1360 & 0.5 \\
\hline
\end{tabular}

* One cigarette burned in $1 \mathrm{~m}^{3}$ air 
除すことにより閾希釈倍数(気中濃度／嗅覚閾值）： Odor Unitを求めると，アセトアルデヒドが最も高 くたばこ煙の臭気に寄与していることが示される( Table 1)。したがって，たばこ煙中に微量でありな がら嗅覚閾值が低いため臭気の原因となる物質が含 まれる事を考慮に入れても，アセトアルデヒドを除 去することにより，たばこ煙に起因する臭気を大幅 に低減できることが期待される。

\section{3. アミノ酸によるアセトアルデヒド除去}

アルデヒドがアミノ酸と化合することによりイミ ンを生成する反応は，よく知られており ${ }^{16)}$ ホルムア ルデヒドの吸着建材では，この手法がよく用いられ ている。<smiles>[R]C=N[C@@H]([R])C(=O)O</smiles>

しかし，この反応は可逆でありイミンの加水分解 により容易にもとのアルデヒドが遊離するとされて いる ${ }^{16)}$ 。下記に述べる開発装置で用いられている薬 液では, 酸化防止剤, キレート剂の存在下で複数の アミノ酸とアルデヒドを反応させることにより，生 成物の安定化が図られているため長時間のアセトア ルデヒド除去効果を有すると考えられる。

\section{4. 方法}

\section{1 開発装置の概要}

評価した開発装置は，前段に浮遊粉じんを除去す るための高性能除じんフィルターとVOCを除去す るための活性炭フィルターにより成る粉じん・ VOC除去ユニット (Particulate and VOC Removal Unit : PVRU)を，後段にアセトアルデヒドなどの含 酸素成分を除去するためのアミノ酸を主成分とした 薬液(アミノ酸成分 $5 \%$ ) を含浸させたウェットエレ メントを有する湿式の臭気除去ユニット（Odor Removal Unit : ORU) を備えている。開発装置の概要 をFig. 1に示す。実験では処理風量を $1200 \mathrm{~m}^{3} \mathrm{~h}^{-1}$ 亡 し, ORUでは薬液10 Lを $3 \mathrm{~L} \mathrm{~min}^{-1}$ の流速で循環さ せた (w/ chemical)。また, 対照として純水10 Lを 同様に循環させた (w/ no chemical)。

\section{2 アセトアルデヒド除去性能の評価}

予備実験としてアセトアルデヒドの除去性能を確 認するため, ボンベガス (2500 ppm)を室内空気に より希釈調製した250 $\mu \mathrm{g} \mathrm{m}^{-3} \sim 600 \mu \mathrm{g} \mathrm{m} \mathrm{m}^{-3}$ のアセ トアルデヒドを含む試料空気をダクトを介して $1200 \mathrm{~m}^{3} \mathrm{~h}^{-1}$ の風量で開発装置に導入し, Fig. 1に示 した(1)装置吸入口(Inlet of PVRU)拈よび(3)装置吹 出口(Outlet of ORU)でアセトアルデヒド濃度を測 定した。

開発装置によるアセトアルデヒドのワンパス除去 率は, 両測定点(1), (3))のアセトアルデヒド濃度を

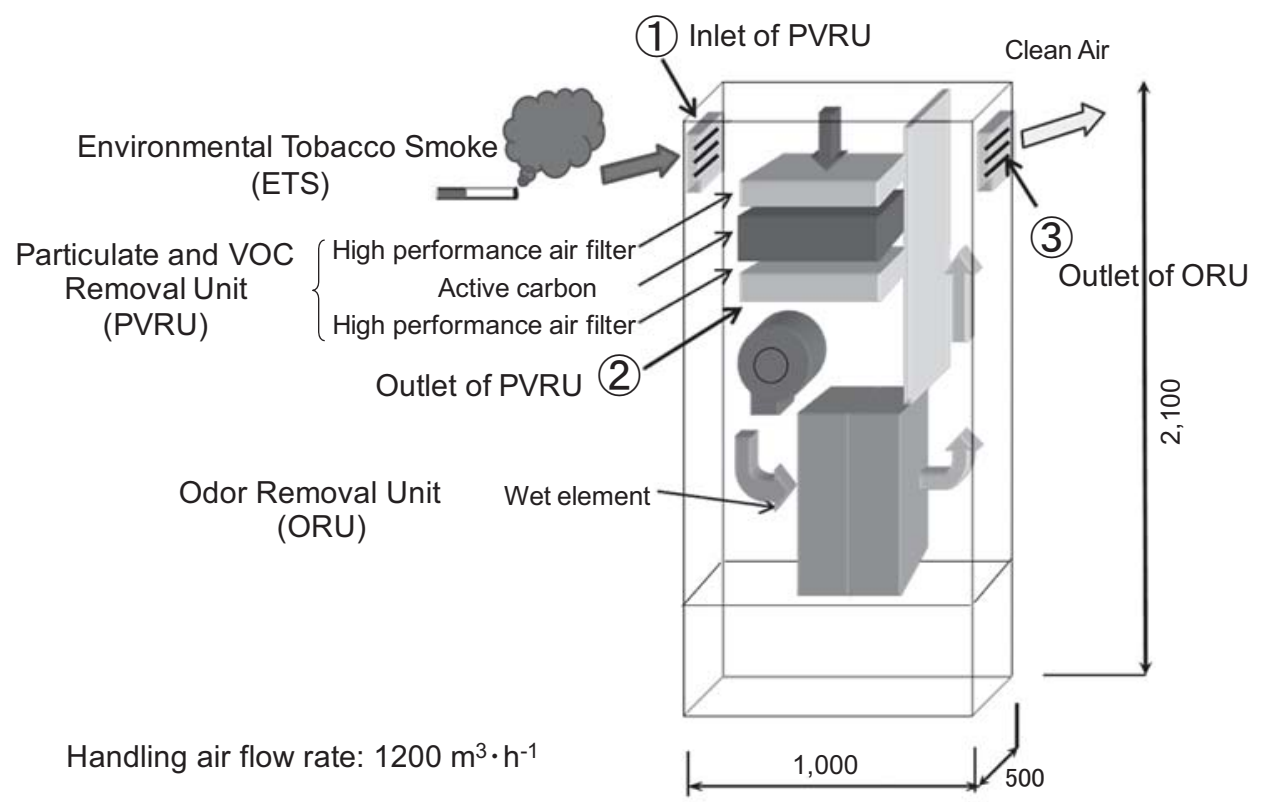

Fig.1 Schematic drawing of ETS removal equipment and sampling points 
（1）式に代入することにより求めた。

$$
\eta(\%)=\left(\mathbf{C}_{\text {inlet }}-\mathbf{C}_{\text {outlet }}\right) / \mathbf{C}_{\text {in }} \times 100
$$

ただし $\eta(\%)$ ：ワンパス除去率， $\mathrm{C}_{\text {inlet }}$ ：装置吸入 口濃度， $\mathrm{C}_{\text {outlet }}$ ：装置吹出口濃度

\section{3 たばこ煙成分除去性能の評価}

たばこ煙成分の除去性能を評価するため，たばこ 5 本または10本を連続的に同時燃焼させることによ り調製したたばこ煙を含む試料空気を全量ダクトを 介して $1200 \mathrm{~m}^{3} \mathrm{~h}^{-1}$ の風量で開発装置に直接導入した。 測定点は(1)装置吸入口(Inlet of PVRU), (2)活性炭フィ ルター後 (Outlet of PVRU), (3)装置吹出口 (Outlet of ORU) としPVRUによる除去成分打よびその効率と ORUによる除去成分およびその効率とを比較した。 PVRUによるワンパス除去率 $\left(\eta_{\mathrm{I}}\right)$ およびPVRU+ ORUによるワンパス除去率 $\left(\eta_{\text {III }}\right)$ は次式により求め た。

$$
\begin{aligned}
& \eta_{\mathrm{I}}(\%)=\left(\mathbf{C}_{1}-\mathbf{C}_{\overparen{2}}\right) / \mathbf{C}_{1} \times 100 \\
& \eta_{\text {II }}(\%)=\left(\mathbf{C}_{1}-\mathbf{C}_{\overparen{3}}\right) / \mathbf{C}_{11} \times 100
\end{aligned}
$$

ただし $\mathrm{C}_{\circledast}$ : 装置吸入口の濃度, $\mathrm{C}_{2}$ ：活性炭フィ ルター後の濃度, $\mathrm{C}_{3}$ 装置吹出口の濃度

さらに，ORUに薬液を含浸させた場合と純水を 含浸した場合のたばこ煙除去効率を比較し，薬液の 除去性能を確認した。また，高負荷条件下に打ける 本装置のたばこ煙除去性能を評価するため，たばこ 10本をのべ400本になるまで連続的に同時燃焼させ, ORUに純水を含浸させた場合と薬液を含浸させた 場合について, 装置吹出口のVOCおよびアセトア ルデヒド濃度を連続測定し両者を比較した。

\section{4 評価項目および分析方法}

評価に用いる項目は，浮遊粉じん，VOC，カル ボニル化合物, アンモニア，臭気とし，サンプリン グポイント (1)(2)(3)にて試料空気を採取し測定を行っ た。各成分の測定方法を以下に示す。

・浮遊粉じん濃度の測定

(1)装置吸入口および(3)装置吹出口において，連 続的に浮遊粉じん濃度を測定した。

使用機器

デジタル粉じん計(柴田科学製：LD-3B)
測定範囲 $\quad 0.001 \sim 10.0 \mathrm{mg} \mathrm{m}^{-3}$

測定感度 $1 \mathrm{CPM}=0.001 \mathrm{mg} \mathrm{m}^{-3}$

測定精度＼cjkstart較正粒子に対して $\pm 10 \%$

・VOCおよびカルボニル化合物濃度の測定

(1)装置吸入口, (2)活性炭フィルター後, (3)装置 吹出口においてVOCおよびカルボニル化合物 濃度を測定した。

$<\mathrm{VOC}>$

サンプリング条件

TenaxTAを充填した加熱脱着チューブに $100 \mathrm{~mL} \mathrm{~min}$-1 $^{-1}$ 流速でポンプを用いて30分 間捕集

分析機器

加熱脱着GC/MS (Agilent Technologies製

6890N/5973Network GERSTEL Master) 定量下限値 $2 \mu \mathrm{g} \mathrm{m}^{-3}$

<カルボニル化合物>

サンプリング条件

DNPHカートリッジ(ジーエルサイエンス製 InertSep mini AERO)に1.5 L $\min ^{-1} の$ 流速 でポンプを用いて30分間捕集した後アセ卜 ニトリル(キシダ化学製 HPLC用)で抽出 分析機器

HPLC(Agilent Technologies製 1100 Series) 定量下限値 $1 \mu \mathrm{g} \mathrm{m}^{-3}$

また，各測定点における有機化合物濃度をプロト ン移動反応質量分析計 (IONICON製PTR-MS) 用い て，SCANモード(単位質量あたり積算時間 $100 \mathrm{mS}$ ) により質量数 21 から 220 まで順次連続測定した。 PTR-MSは, 従来の捕集剤及び機器分析では検出が 困難な含酸素物質も含む広範なVOCを高感度で分 析できる装置である。PTR-MSでは，水よりもプロ トン親和性の高い物質 $(\mathrm{R})$ がドリフトチューブ内で 水由来の $\mathrm{H}_{3} \mathrm{O}^{+}$と反応し(陽子移動反応), $\mathrm{RH}^{+}$として 質量分析計で検出される。

$$
\mathrm{R}+\mathrm{H}_{3} \mathrm{O}^{+} \rightarrow \mathrm{RH}^{+}+\mathrm{H}_{2} \mathrm{O}
$$

$\mathrm{H}_{3} \mathrm{O}^{+}$イオンの濃度 $\left[\mathrm{H}_{3} \mathrm{O}^{+}\right]$は $[\mathrm{R}]$ に比べて大過剩であ るため, 陽子移動反応は擬一次反応とみなすことが

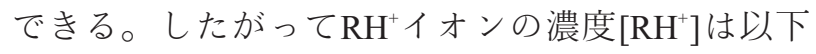
の式(4)で表すことができる。ただし， $k$ は陽子移動 反応速度定数 $2.0 \times 10^{-9}\left[\mathrm{~cm}^{3} \mathrm{~s}^{-1}\right], t$ は $\mathrm{H}_{3} \mathrm{O}^{+}$イオンとの 反応時間[s]である。 


$$
\left[\mathrm{RH}^{+}\right]=[\mathrm{R}]_{0}\left(1-\mathrm{e}^{-\mathrm{k}\left[\mathrm{H}_{3} \mathrm{O}^{+}\right]_{t}}\right) \approx\left[\mathrm{H}_{3} \mathrm{O}^{+}\right]_{0}[\mathrm{R}]_{0} \cdot k t
$$

さらにイオン検出器で測定されたそれぞれのイオ ンカウント $\left[\mathrm{H}_{3} \mathrm{O}_{[\text {count }]}^{+}\right],\left[\mathrm{RH}_{\text {[count] }}^{+}\right.$は各イオン濃度と比 例するので, 最終的に測定物質の濃度 $[\mathrm{R}]$ は, $\mathrm{H}_{3} \mathrm{O}^{+}$ イオンの透過率を $\operatorname{Tr}\left(\mathrm{H}_{3} \mathrm{O}^{+}\right)$, 測定物質 $\mathrm{R} の$ 透過率を

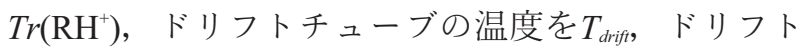
チューブの圧力を $P_{\text {drif }}(\mathrm{Pa})$, アボガドロ数を $\mathrm{N}_{\mathrm{A}}$ とす ると, 式(5)で示される $\mathrm{ppbV}$ 単位での体積混合比で 表すことができる。

$$
\begin{aligned}
{[\mathrm{R}]_{0} } & =\frac{\left[\mathrm{RH}_{\text {[count] }]}^{+} \cdot \operatorname{Tr}\left(\mathrm{H}_{3} \mathrm{O}^{+}\right)\right.}{\left[\mathrm{H}_{3} \mathrm{O}_{\text {[count }]}^{+}\right] \cdot \operatorname{Tr}\left(\mathrm{RH}^{+}\right) \cdot k t} \\
& \times\left[\frac{8.314 \times T_{\text {drift }}}{\mathrm{N}_{\mathrm{A}} \times P_{\text {drift }} \times 1 \times 10^{-6}}\right] \times 10^{9}
\end{aligned}
$$

したがって，各測定点に扮ける試料空気をPTRMSによって測定し, 式(1)（2）(3)に代入することに より，たばこ煙に含まれるほぼ全てのVOCの除去 性能を評価できると考えられる。

・アンモニア濃度の測定

(1)装置吸入口, (2)活性炭フィルター後, (3)装置 吹出口においてアンモニア濃度を測定した。

（外部分析機関委託）

定量方法

ホゥ酸溶液吸収インドフェノール青吸光光

度法

定量下限値 $\quad 10 \mu \mathrm{g} \mathrm{m}^{-3}$

・一酸化炭素の測定

(1)装置吸入口および(3)装置吹出口において，一 酸化炭素濃度を測定した。

使用機器

定電位電解測定計測器 (柴田科学製 COX-2) 測定範囲 $\quad 0 \sim 50 \mathrm{ppm}$

最小目盛 $\quad 0.1 \mathrm{ppm}$

測定精度 $\pm 5 \%$
・臭気の測定

(1)装置吸入口, (2)活性炭フィルター後, (3)装置 吹出口において臭気濃度を測定した。（外部分 析機関委託)

測定方法 三点比較式臭袋法 ${ }^{17}$ (排出口法)

\section{5. 結果および考察}

\section{1 アセトアルデヒド単独ガスの除去性能}

開発装置にアセトアルデヒドガスを導入した際の (1)装置吸入口および(3)装置吹出口におけるアセトア ルデヒド濃度をTable 2に示す。なお濃度測定は, 装置の吸入口㧍よび吹出口それぞれの右, 中央, 左 で行い, 平均したものを各部位の測定値とした。

各測点においてアセトアルデヒド濃度を測定し， (1)装置吸入口抢よび(3)装置吹出口のアセトアルデヒ ドの平均濃度から (1)式を用いてアセトアルデヒド 除去率を計算したところ, 導入されたアセトアルデ ヒド濃度に関わらず開発装置による除去率は拉よそ 95\%であり，（装置吹出口の濃度は，いずれも室内 濃度指針值である $48 \mu \mathrm{g} \mathrm{m}^{-3}$ 以下であった。

厚生労働省の報告によれば，副流煙中に含まれる アセトアルデヒドは1本当たりおよそ1600 1900 $\mu \mathrm{g}$ とされる ${ }^{10)}$ 。本実験では最高 $363 \mu \mathrm{g} \mathrm{m}^{-3}$ のアセ トアルデヒドガスを $1200 \mathrm{~m}^{3} \mathrm{~h}^{-1}$ の風量で開発装置に より処理し, $19 \mu \mathrm{g} \mathrm{m}^{-3}$ まで低減することが可能で あったことから, 毎分約 $7 \mathrm{mg}$ のアセトアルデヒド を除去できる性能を持つと考えられる。これは，た ばこの燃焼時間を5 min cigarette $^{-1}$ とすれば，およそ 毎分19本分のたばこ煙を処理できる性能に当たる。 以上の結果から本装置は厚生労働省による室内濃度 指針值である48 $\mu \mathrm{g} \mathrm{m}^{-3}$ の7.6倍の濃度のアセトアル デヒドガス，または19本の同時喫煙があった場合に 発生するアセトアルデヒドを $1200 \mathrm{~m}^{3} \mathrm{~h}^{-1}$ の風量で導 入した場合でも $95 \%$ のアセトアルデヒドを除去する

\begin{tabular}{|c|c|c|c|c|c|c|c|c|}
\hline \multicolumn{4}{|c|}{ Inlet $\left(\mu \mathrm{g} \mathrm{m}^{-3}\right)$} & \multicolumn{4}{|c|}{ Outlet $\left(\mu \mathrm{g} \mathrm{m}^{-3}\right)$} & \multirow{2}{*}{$\begin{array}{c}\text { Removal } \\
\text { efficiency } \\
(\%)\end{array}$} \\
\hline Right & Center & Left & Ave. & Right & Center & Left & Ave. & \\
\hline 131 & 148 & 134 & 138 & 6 & 11 & 7 & 8 & $94 \%$ \\
\hline 226 & 279 & 256 & 254 & 9 & 16 & 11 & 12 & $95 \%$ \\
\hline 310 & 404 & 376 & 363 & 11 & 29 & 15 & 19 & $95 \%$ \\
\hline
\end{tabular}
性能を有するむのと考えられた。

Table 2 Acetaldehyde concentrations at inlet of PVRU, outlet of ORU and removal efficiency 


\section{2 たばこ煙の除去性能}

Fig. 2にたばこ10本を同時に自然燃焼させた際の (1)装置吸入口, (2)活性炭フィルター後, (3)装置吹出 口（臭気除去ユニットに純水を含浸させた場合と薬 液を含浸させた場合)の試料空気中VOCをPTR-MS により測定した結果を示す。

吸入口のスペクトル(1) Inlet of PVRU)に示した 通り，たばこ煙には多種類のVOCが含まれており， 中でも mass 45 (アセトアルデヒドの分子量+1)に示 されるアセトアルデヒドの含有率が高い。さらに活 性炭フィルター後のスペクトル(2) Outlet of PVRU) から，たばこ煙中のVOCは分子量の大きい物質を 中心にPVRUにより除去されることが示された。し かし低分子量含酸素物質であるアセトアルデヒドの 除去性能は十分ではなく，室内濃度指針值である 30 $\mathrm{ppb}\left(48 \mu \mathrm{g} \mathrm{m}^{-3}\right)$ を大きく上回った。次に後段に設 置されたORUに純水を含浸させたもの(3) Outlet of ORU, w/ no chemical)では, アセトアルデヒドが親 水性であり, 水に容易に溶解することから除去が可
能であると考えられたが，短時間でアセトアルデヒ ドの水への溶解が飽和に達してしまうため, 顕著な 除去効果はみられなかった。これに対して薬液を含 浸させた場合 (3)Outlet of ORU, w/ chemical)では, アセトアルデヒド濃度は $20 \mathrm{ppb}$ 以下まで低減された。

Fig. 3にPTR-MSを用いて順次サンプリングポイ ント（1)，(2)，(3))を切り替えて測定したトルエン (上図) およびアセトアルデヒド (下図)の濃度とその 経時变化を示す。

Fig. 3に示された(2)活性炭フィルター後の濃度よ り，トルエン濃度はPVRUによって大きく低減され たが，PVRU後のアセトアルデヒド濃度は吸入口よ りは低減されるあのの室内濃度指針值にまでは 至らず，経時的に上昇した。(3)装置吹出口に示され る後段のORUでは純水を含浸させた場合 (w/ no chemical)アセトアルデヒドはほとんど除去されな かったが，薬液を含浸させた場合(w/ chemical)で は大きく低減された。さらにORU(w/ chemical) で 試料空気を処理することにより二次生成したと考え
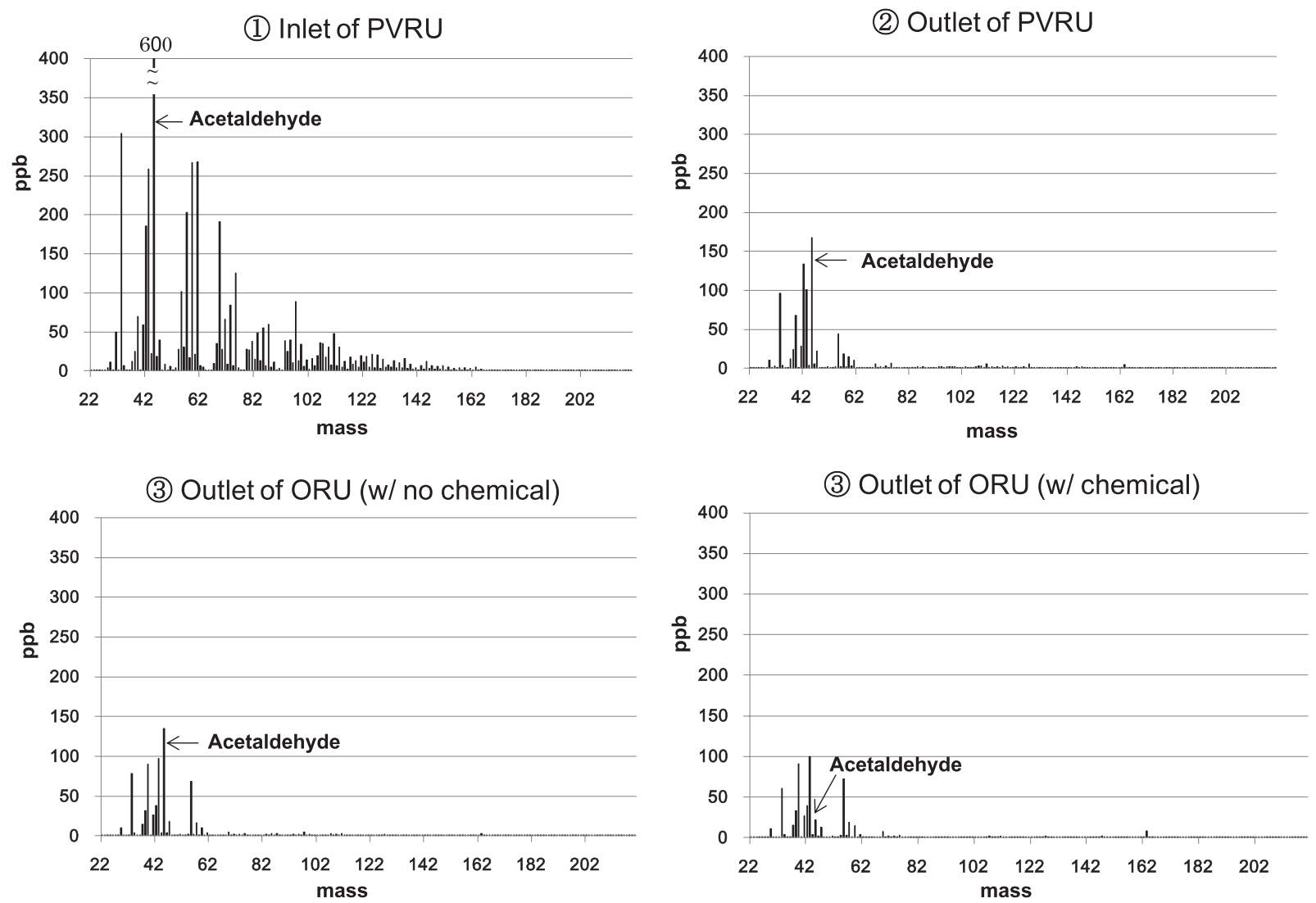

Fig.2 PTR-MS spectrums at Inlet of (1)PVRU (Particle and VOC Removal Unit), (2)Outlet of PVRU and (3) Outlet of ORU (Odor Removal Unit).

w/ no chemical : using water at $\mathrm{ORU}, \mathrm{w} /$ chemical: using chemical liquid at $\mathrm{OR}$ 
Toluene

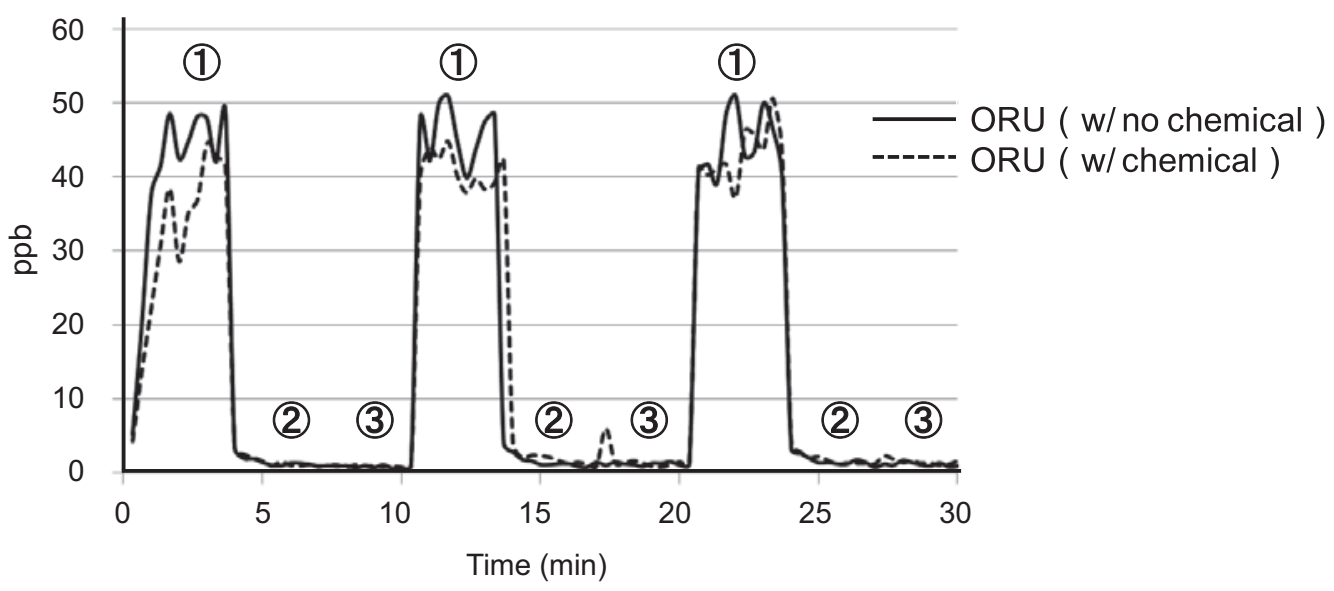

Acetaldehyde

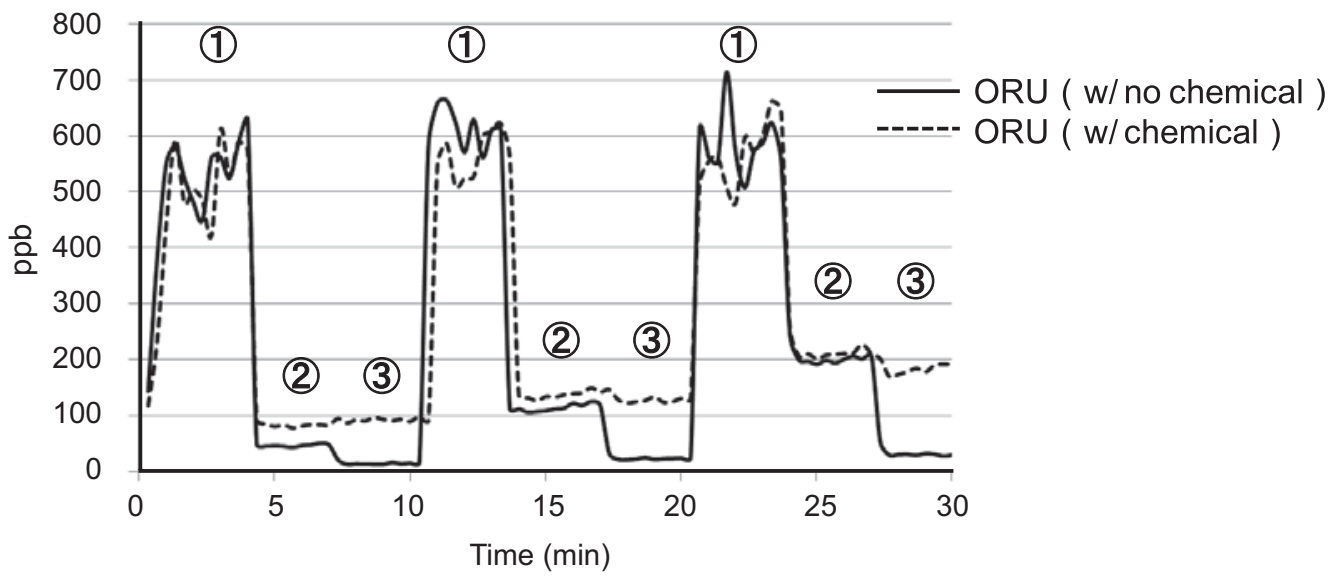

Fig.3 Concentrations of toluene (above) and acetaldehyde (bellow) at Inlet of (1)PVR (Particle and VOC Removal Unit), (2) Outlet of PVRU and (3) Outlet of ORU (Odor Removal Unit). Number of burning cigarettes was 10. w/ no chemical : using water at ORU, w/ chemical: using chemical liquid at ORU

られる新たな物質は検出されなかった。

以上の結果から, 試料空気中のアセトアルデヒド は単に水溶液中に溶解しているだけではなく, 薬液 に含まれるアミノ酸との化学結合により安定な物質 として溶解しており，これにより長時間のアセトア ルデヒド除去性能を維持できたものと考えられる。 たばこ5本および10本同時燃焼させた際のトルエン のPVRUによるワンパス除去率を式(2)から，PVRU およびORUによるワンパス除去率を式(3)から求め た結果をFig. 4に示す。また同様にアセトアルデヒ ドのワンパス除去率をFig. 5に示す。

Fig. 4に示した通りトルエンでは, PVRUにより 90\%以上が除去されることが示された。一方, アセ トアルデヒドではPVRUによる5本燃焼時，10本燃 焼時の初期除去率： $\eta_{\mathrm{I}}$ がそれぞれ $84 \% ， 80 \%$ ，その
後時間経過とともに除去率が低下し，30分後では5 本燃焼時で $60 \%, 10$ 本燃焼時で $30 \%$ であった。さら に後段のORUによる除去を加えた除去率： $\eta_{\text {II }}$ は， PVRU+純水含浸ORU(w/ no chemical)では，30分後 に5本燃焼時で $80 \% ， 10$ 本燃焼時で40\%まで除去率 が低下した。これに対してPVRU+薬液含浸ORU(w/ chemical）では，5本燃焼時10本燃焼時ともに30分後 でも90\%以上の除去率を維持した。したがって，ア セトアルデヒドの活性炭フィルターへの吸着量は, 時間経過とともに低下するものと考えられる。後段 のORUでは, 純水含浸では活性炭フィルター通過 空気の処理を行ってもアセトアルデヒドの除去効果 は短時間しか持続しなかったが，薬液含浸の場合長 時間除去効果が持続した。したがってORUによる アセトアルデヒド除去効果は, 水への溶解だけでは 

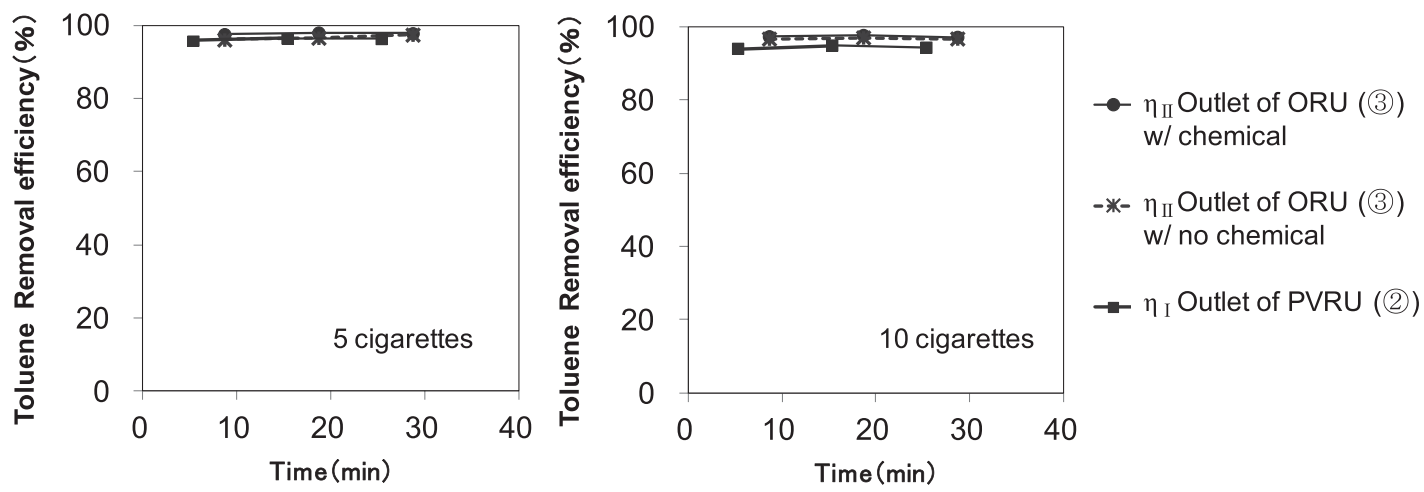

Fig.4 Toluene removal efficiency at (2) Outlet of PVRU (Particle and VOC Removal Unit), $\eta_{\mathrm{I}}$ and (3) Outlet of ORU (Odor Removal Unit), $\eta_{\mathrm{II}}$.

w/ no chemical : using water at ORU, w/ chemical: using chemical liquid at ORU
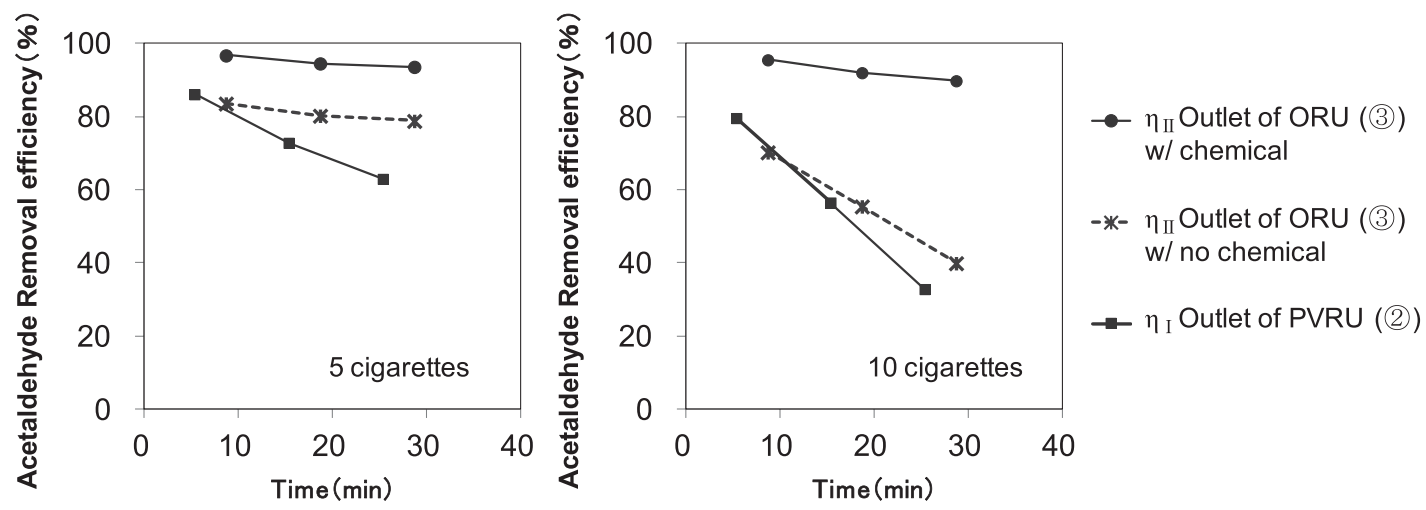

Fig.5 Acetaldehyde removal efficiency at (2) Outlet of PVRU (Particle and VOC Removal Unit), $\eta_{\mathrm{I}}$ and (3) Outlet of ORU (Odor Removal Unit), $\eta_{\mathrm{II}}$.

w/ no chemical : using water at ORU, w/ chemical: using chemical liquid at ORU
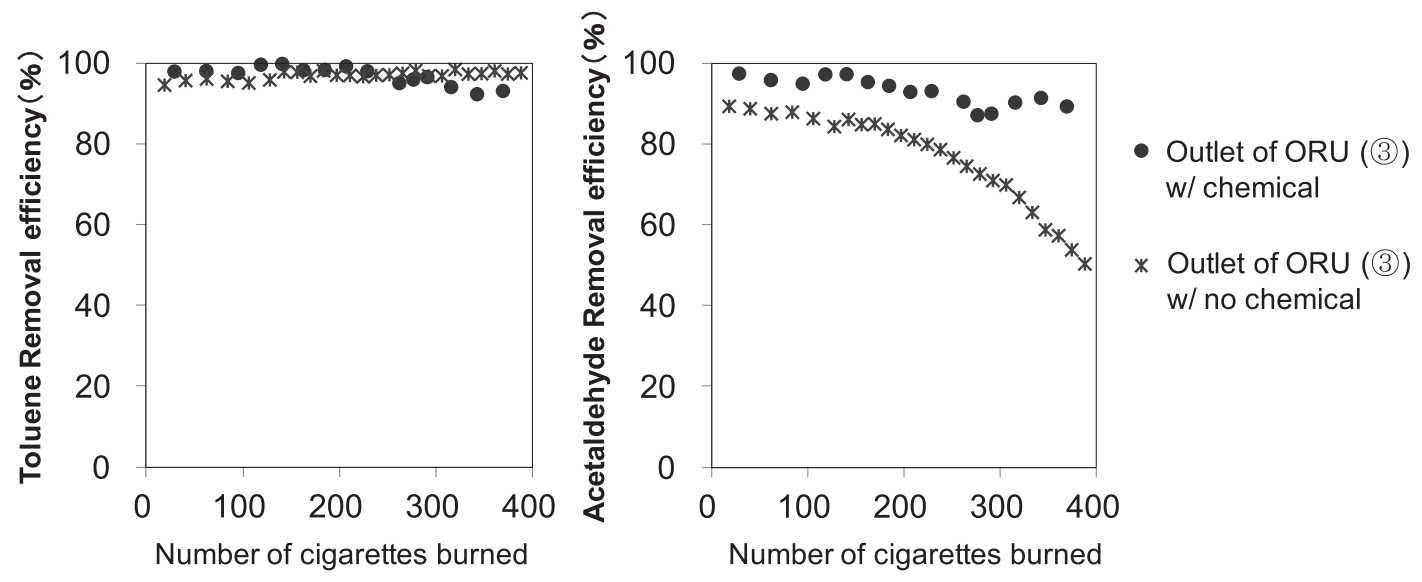

Fig.6 Long term endurance test of removal efficiency.

W/ no chemical : using water at ORU,

w/ chemical : using chemical liquid at ORU 


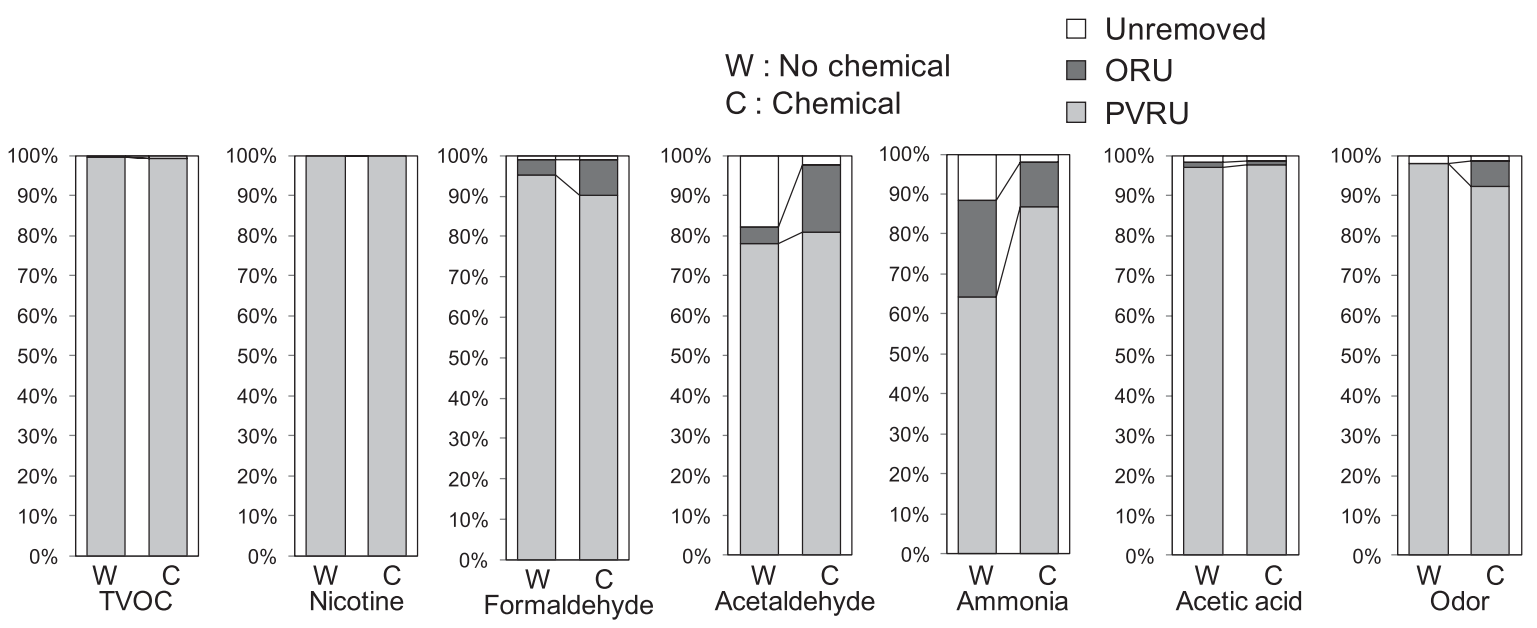

Fig.7 Removal efficiency of ETS by PVRU (Particle and VOC Removal Unit) and ORU (Odor Removal Unit).

W: using water at ORU, C: using chemical liquid at ORU

なく薬液中のアミノ酸との化学結合による化学吸着 による効果であると考えられる。

さらに，開発装置によるたばこ煙除去性能の高負 荷耐久性を確認するため，たばこの同時 10 本燃焼を 計400本(約4時間)になるまで継続し, 装置吹出口の アセトアルデヒドおよびトルェン濃度の経時変化を PTR-MSによって測定した。結果をFig.6に示す。

Fig. 6より, 開発装置のトルエンの除去率はORU に純水を含浸させた場合, 薬液を含浸させた場合と もに $90 \%$ 以上を持続した。一方アセトアルデヒドの 除去率はORUに純水を含浸させた場合は徐々に低 下し，400本燃焼後では50\%以下となったが，ORU に薬液を含浸させた場合は，400本燃焼後でも約 90\%の除去率を持続した。したがって本実験で用い た薬液10 Lでは, たばこ煙400本，アセトアルデヒ ドに換算しておよそ700 mgを化学吸着しているこ とから, 本薬液のアセトアルデヒド吸着容量は 70 $\mathrm{mg} \mathrm{L} \mathrm{L}^{-1}$ 以上であると考えられる。

次に主なたばこ煙成分であるTVOC，ニコチン， ホルムアルデヒド，アセトアルデヒド，アンモニア， 酶酸の成分分析扔よび臭気測定から求めたPVRUお よびORUによるたばこ成分除去率をFig. 7に示す。

Fig. 7よりニコチンを始めVOCの多くはPVRUに よりほとんど除去されたが，アセトアルデヒド，ア ンモニアは十分除去することができず, 薬液を含浸 させたORUを通過させることにより $95 \%$ 以上除去さ れることが成分分析によっても示された。また，臭 気屯薬液を含浸させたORUを通過させることによ
り 99\%低減することが示された。

以上の結果から PVRU $+\mathrm{ORU}(\mathrm{w} /$ chemical) を備え た開発装置では, 活性炭フィルターでは除去できな いアセトアルデヒド，アンモニア等の臭気物質の除 去が可能であることが示された。ただし活性炭フィ ルターに保持されたこれらの成分は, 時間経過に伴 い吸着速度が遅くなり, 結果的に吸着容量を超える ためPVRUを通過する空気中の濃度が上昇し, 薬液 の除去性能を超える量がORUに導入される可能性 がある。よって開発装置を長期間運転する場合には, PVRUからこれらの成分の脱離を行うかPVRUの交 換をする必要があると考えられる。

\section{6. 結論}

除じんフィルターおよび活性炭フィルターを用い た既存の空気清浄手法(PVRU)に加え, 臭気成分の 除去を目的としたアミノ酸を主成分とする薬液(化 学吸収液)による臭気除去ユニット（ORU）を備えた 新たな空気清浄装置(開発装置)について，アセトア ルデヒド，たばこ煙の除去性能を調査したところ以 下の知見を得た。

(1) 開発装置によって139 $\mu \mathrm{g} \mathrm{m}^{-3} \sim 347 \mu \mathrm{g} \mathrm{m}^{-3}$ の アセトアルデヒドを含む試料空気を $1200 \mathrm{~m}^{3} \mathrm{~h}^{-1}$ の風量で処理したところ, ワンパス除去率およ そ95\%を達成した。

(2) 開発装置によってたばこ煙(5本同時連続燃焼ま たは10本同時連続燃焼)を $1200 \mathrm{~m}^{3} \mathrm{~h}^{-1}$ の風量で 処理したところ，ワンパス除去率として粉じん， 
ニコチン等主なたばこ煙成分についてほぼ100 $\%$ ，アセトアルデヒド $95 \%$, アンモニア $98 \%$ を 達成した。またこの時の臭気濃度低下率は $99 \%$ であった。さらにこの性能は，たばこ10本同時 連続燃焼を400本まで行った時点でもほぼ持続 した。

(3) 活性炭フィルター通過後のアセトアルデヒド濃 度測定により，PVRUのみによるアセトアルデ ヒド除去率は経時的に低下したことから，アセ トアルデヒドは短時間のうちに活性炭フィルター への吸着量が減少したことが示された。

(4)たばこ煙を開発装置によって処理した試料空気 をPTR-MSによって测定したところ，処理に伴 う二次的な生成物は検出されなかった。

\section{引用文献}

1）JIS C 9615-1995, 空気清浄機 日本工業規格.

2）JACA No.15-1980, ガス除去用空気清浄装置設 置基準 社団法人日本空気清浄協会.

3）林敏昭, 汲田幹夫, 大谷吉生 : 添着活性炭のア セトアルデヒド吸着性能の劣化, 化学工学論文 集，32，72-78(2006).

4）大谷吉生：たばこ煙のろ過, 喫煙科学研究の歩 みー1996年から2005年一受動喫煙, 喫煙科学研 究財団, (2007).

5）八太 豊：喫煙現場における分煙と空気清浄, エアロゾル研究，23，246-251(2008).

6）野崎敦夫, 清澤裕美, 吉澤 晋: 家庭用空気清 浄機の污染物質除去性能と室内濃度予測に関す る研究(その1)環境夕バコ煙に対する除去効果, 日本建築学会環境系論文集，576，37-42(2004).

7）南野 脩, 三原章裕, 品田宜輝: 小型空気清浄
機の性能評価とその応用に関する研究 第1報一 浮遊粉じん除去性能に関する研究, 空気調和・ 衛生工学会論文集, 69，49-59(1998).

8）JIS B 9901-1997 ガス除去フィルタ性能試験 方法 日本工業規格.

9）内山巌雄 : 受動喫煙対策について, 空気調和・ 衛生工学, 78, 19-23(2004).

10）宮崎竹二：喫煙環境中におけるアセトアルデヒ ド，ホルムアルデヒド濃度，生活衛生， 48,18 1-190(2004).

11）長谷川あゆみ：タバコ由来の化学物質による喫 煙の分煙効果の評価について, SCAS NEWS, 2007- II ， 3-5(2007).

12) Otani Y., Namiki N., Yun C.-M., Emi H.: Simultaneous removal of particulate and gaseous cigarette smoke components by corona discharge, Proc. of $7^{\text {th }}$ Int Conf on Indoor Air Qualith and Climate, Nagoya, 4, 51-56 (1996).

13）島津製作所，タバコ臭の評価 島津アプリケー ションニュース，No.F34（2005）.

14）厚生労働省，平成11-12年度たばこ煙の成分分 析について(概要).

http://www.mhlw.go.jp/topics/tobacco/houkoku/ seibun.html

15）永田好男，竹内教文：三点比較式臭袋法による 臭気物質の閾值測定結果，日環セ所報，17，7789 (1990).

16) Pine S. H. : Organic Chemistry, $5^{\text {th }}$ Ed., McGrawHill, p.248 (1987).

17）岩崎好陽：新訂 臭気の嗅覚測定法 三点比較 式臭袋法測定マニュアル，社団法人におい・か おり環境協会，54-98(2005). 